\title{
Corporate Governance and Presence of Women Director on Boards"-
}

\author{
Mahalakshmi. $V^{1,}$ Dr. P.Narayana Reddy ${ }^{2}$ \\ ${ }^{1}$ Faculty Sheshadripuram College, Sheshadripuram, Pursuing Ph.D in Reva UniversityBangalore. \\ ${ }^{2}$ (Hyderabad University) Director School of Business studies Reva University.
}

\begin{abstract}
The essence of Corporate Governance practices in the new Millennium is construed to mean something beyond the formal demonstrations and exhibitions of accountability and trust. The appropriateness of corporate governance can be felt only by giving regard to the assessment of competencies and behavioral skills of the Board of Directors. The companies with the goal of composing boards with integrity and expertise are dipping into new pools of candidates including women. Yet some of the large companies still have no women directors.In this paper an attempt is made to find answer for the question, "Are there enough qualified, competent and skilled women directors available to substantially increase the representation of women on boards". The paper also poises certain examples, where women have proved competence, appropriateness and trust around the world. Further the paper also examines whether fortune Indian companies which has made its position on global fortune 500 companies has women directors on the board.
\end{abstract}

Keywords: Corporate Governance, Women Directors, qualified and competent women talent pool, Indian companies on fortune 500 companies.

\section{Introduction}

Globalization has not only significantly heightened business risks, but has also compelled Indian Companies to adopt international norms and good governance.Much has been heard, talked and said about the topic of Corporate Governance, but unfortunately the parameters to judge its practical implementation is still not very clear. Corporate Governance is an enduring process that requires integrated efforts and in today's highly specialized times it is indispensable to be specialists to achieve excellence. The corner stone of effective corporate governance practices is imbedded in virtues and intellectual honesty that obviously extends beyond the structural form of corporate law and governance which is naturally present in every women to handle situations more extensively. Manager's accountability to shareholders and corporations responsibility to society is two important objectives of corporate governance. Therefore The practice of good corporate governance has become a necessary prerequisite for the effective management of any corporation to sustain with the global standards. All These requirement beyond the Corporate Governance concepts can be conveniently fulfilled by the presence and involvement of Women Directors in the decision making process of the companies which leads to Nation's overall economic growth and good corporate governance. The corporate India scorecard, when assessed for the number of women in the corporate boardroom, falls greatly short of the global benchmarks. In India just a handful of the top 500 companies would have a woman on their board. Now the question arises whether there are enough woman talents available to represent on the boards of Indian companies, in this context Corporate India will need to search answers to the questions like, Are there enough women talents to bring in the best ideas, resources, expertise and best practices that will increase the shareholders return and build a lasting company with strong value and culture, over time. If this statement is clearly understood by the corporate world it will open greater acceptability for bringing in the rich sensitivity, perception, thinking process and work experience of women executives to enrich the boardroom discussion beyond the narrow limits of legal compliance and make the Company more vibrant, robust and responsive to the workplace..

Beyond the consideration of Women Directors serving on Fortune 1000 boards on the Globe, it is the search for available talents which reflects the success of the boards. The Institutes conducting Professional courses are the place of available knowledge pools from where the companies get the talents which later emerge as knowledge full, talented think-tanks in the course of time becoming eligible for boards seats. Women holding key positions in India and other countries provide a proof of their competence and trust.

This study based on secondary data can be divided into three groups. The first group of study refers to understanding the theoretical concept of corporate governance based on the studies made in India and abroad using secondary data only. The second group studies the data of Professional Institutions in India like ICAI, ICSI, ICWA, Bar council of India, Women CEOs in India were taken up for the study(online information and website andreports)to identify the available women talent pool who become eligible to take up executive positions in companies, later this pool of talents can be considered for company boards. 
SEBI under clause 49 has observed that Associate members of these institutions will be eligible to get selected as Independent Directors of listed companies in India. The findings and analysis of this study can be considered as one of the answer to the question, whether there are enough women talents available to represent Indian boards. The third group of study refers to checking the presence of women on Indian companies which has made its place on global fortune 500 companies 2010. The study also reviews answers to some important questions like why women on board?, and how women has proved competence and trust in corporate by referring studies made on this topic.Further the paper studies about women executives successfully representing fortune companies who are been recognized for their untiring job which has made the world to admire them in India and abroad the information is collected through newspaper and online news which is a proof of competence and trust of presence of women on boards.

The standards for corporate governance took roots in US and UK and subsequently spread to other countries. The Cadbury Committee Report hurled pressures on the Confederation of Indian Industries (CII), The Associated chamber of Commerce and Industry (ASSOCHAM) and the Securities Exchange Board of India (SEBI) to form committees and suggest recommendation for the same. Hence, SEBI constituted the Kumar Mangalam Birla Committee in 2000 to suggest recommendations of mandatory and non-mandatory nature in additional clause 49 of the listing agreement. This Committee on Corporate Governance emphasized that, strong Corporate Governance is indispensable to resilient and vibrant instrument of investor protection.

\section{Literature review:}

To begin with, the study contributes to extant literature on the topic "Corporate Governance" by understanding an empirical investigation of previously theoritised notion.

\section{Studies made abroad:}

To quote the words of J.Wolfensohn, the former President of the World Bank, "Corporate Governance is about promoting corporate fairness, transparency and accountability". A timely and accurate disclosure of information regarding the financial situation, performance, ownership, control and governance of the company is an important part of corporate governance. Xavier Vives has studied that different systems of Corporate Governance have different impacts on the degree of competition in the economy. Board diversity creates positive benefits for the management of large corporations (cf.Bilimoria, 2000). By incorporating socially legitimated elements (women on the corporate Boards, "Women Directors") firms increase their institutional legitimacy and enhance their likely success (cf.meyer and Rowan, 1977).

\section{Studies made in India:}

Vibha Sinha has equated the terms satisfactory accounting and disclosure with corporate governance, she has emphasized keys to good corporate governance apart from their fundamental functions in regard to ensuring transparency, accountability, fairness and responsibility. She measures the efficiency of the board in terms of monitoring companies' performance against its objectives. Finally she has strongly stressed the idea of corporate governance rating to improve the standard of corporate governance in India.

The union Finance Minister, Mr.P.Chidambaram, has expressed concern over the lack of seriousness on the part of corporate India in following the principles of corporate governance.

\section{Objectives:}

1. To examine and identify eligible Women talent pool available in India to occupy positions on the Boards of Indian Companies.

2. To examine the presence of Women on board of Indian companies which has entered the list among fortune 500 companies listed by, USA in a study.

3. To considerably answer the question Why women on Board?.

\section{Methodology}

1. The study is based on secondary data by drawing information from annual reports of the chosen companies and websites of respective companies were studied particularly to view and check the actual name and posting on the website about the presence of women director on their board.

2. Secondly the membership records (female) in Professional institutions in India from 2010-2015.

- Institute of Chartered Accountants of India

- Institute of Cost and works accountants of India

- Institute of Company Secretaries of India

- Indian Bar council

- Data of No. of Women CEOs 
Were studied to extract the information about no. of women members available who can be eligible to occupy the position on board of Indian companies.

\section{Analysis of Data:}

1.

Reference (secondary data) based survey shows the following results.

Data: Women members from the following areas:

1. The Institute of Chartered accountants of India (2014)

2. The Institute of Company secretaries of India

3. Women in Law profession in India (2014Indian bar council

4. Women CEOs in India (study by ET2016 out of 100 listed companies in india 17 are women CEOs)

Analysis and interpretation:

India female work force is (India sensus 2014) $27 \%$

Let India's female workforce $27 \%=100$

Total \%age of talent Pool available $=21.1 \%+20 \%+22.11 \%+17 \%=80.21$

$$
400 \times 100=20.05 \%
$$

1.1: A Pie chart showing Total \%age of Women talent pool available out of total Women work force in India.
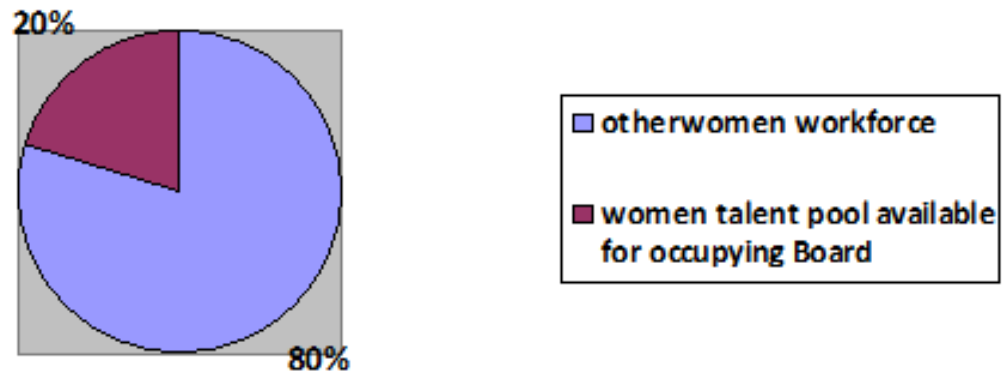

Interpretation:

Figure 1

The above chart indicates out of total women workforce in India only $20 \%$ ( out of $27 \%$ of women force who are working in different sector in India as per 2014 senses) of women are professionals are available for occupying Board position and $80 \%$ of women workforce are in other sectors like agriculture, small industry, artisan, self employed, education managers etc.

2. Data about No.of listed Public sector undertakings in india and required Women talent for Boards:

\begin{tabular}{|l|l|}
\hline $\begin{array}{l}\text { Current Population of India in } \\
2016\end{array}$ & $\begin{array}{l}1,349,451,902 \text { (1.34 billion) As of December 30, } \\
2016\end{array}$ \\
\hline Total Male Population in India & $696,856,962$ (696 million) \\
\hline Total No of Females in India & $652,594,939$ (652 million) \\
\hline
\end{tabular}

Table 1

$\Rightarrow$ Therefore No. of Women talent available for board:

652 million

- 20 - 65.2 million women talent pool available

100

(as per figure 1 women talent available is $20 \%$ ). 
Assumption:It is assumed that women candidates who are identified as women talent pool available out of studies and informations from secondary data of 2014 considered for population of 2016 because it is assumed that in 2016 the same women talent pool prevails in the society in different high positions.

3. Statement showing number of women talent required to fill PSUs in India:

\begin{tabular}{|l|}
\hline No. of Listed PSUs India \\
\hline No. of Women talent required to fill \\
\hline Boards of PSUs (2 on a board)175x $2: 350$ \\
\hline No. of Women talent pool available in India is 65.2 million \\
\hline
\end{tabular}

Table 2

Interpretation: From the above analysis it is clear that the presence or availability of Women talent pool eligible to fill Board positions are 65.2 million available in India which is very huge number which can be considered by all the PSUs/companies in India to fill at least 350 talented women. The companies in India should go for getting women on board for the benefit of the company.

Examining the presence of women on board of Indian companies which has made its place on fortune 500 companies' global list. 10 Indian companies are included in the latest global fortune 500 Companies list.

The league of 500 elite companies for 2015 is topped by U.S. retailer Wal-Mart Stores. The Indian companies on the list:I

Statement showing 10 Indian Companies on fortune 500 companies' global list and No. of women on the boards of these companies:

\begin{tabular}{|l|l|l|}
\hline & INDIAN COMPANIES & No. of women on Board \\
\hline 1 & IOCL & 1 \\
\hline 2 & Reliance India Limited & 1 \\
\hline 3 & State Bank of India & 2 \\
\hline 4 & Bharath petroleum Corporation Limited & 1 \\
\hline 5 & Hindustan Petroleum & 2 \\
\hline 6 & Tata Steel & 1 \\
\hline 7 & Oil and Natural Gas Corporation & 0 \\
\hline 8 & Hindalco Industries Ltd. & 1 \\
\hline 9 & Tata consultancy services Itd. & 1 \\
\hline 10 & Bharathi Airtel Ltd. & 10 \\
\hline & Total & \\
\hline
\end{tabular}

Table 3

From the above statement drafted from information drawn by a pilot view of information from respective websites, we identify that 10 companies which are being identified among fortune 500 companies by USA based survey, No. of Women on Board is maximum 2 members and two elitecompanies like ONGC and Hindalco Industries has no Women members on the board. On an averge of One women on each board 10 elite companies have 10 women members in India.

'(THE HINDU, online edition of India's National Newspaper, Monday, July 12,2010, www.hindu.com) 


\section{WOMEN SERVING ON BOARD}

\section{Why Women on Board:}

With Post-Enron, Satyam and other corporate disasters, companies should look to women to bring fresh ideas and perspectives to their companies, The time is ripe, when compared to earlier years there is increased pool of qualified women and there is an increased need on the part of corporations to widen their net in their director searches. Women bring a collaborative leadership style that benefits boardroom dynamics by increasing the amount of listening, social support, and win-win problem-solving. Although women are often collaborative leaders, they do not shy away from controversial issues. Board directors and business leaders from leading companies have discussed strategies to increase female representation on boards and in executive position at colloquium for women.

One of the study in May 2002 conducted by the Conference Board of Canada published findings of their study on women and corporate governance. The report suggests link between female number on board and corporate governance credentials. It found that

More gender balanced board tended to:

- Pay more attention to audit and risk oversight

- More often considered the needs of more categories of stakeholders.

- Examine a wider range of management and organizational performance.

- $94 \%$ of boards with three or more women insist on conflict-of-interest guidelines.

- It is also found that $72 \%$ of board with 2 or more women conducts formal board performance evaluations while only $49 \%$ of all male board do.

- Organization that provide board of directors with formal orientation programme have a greater\% age of women directors than do organizations with no such programme.

Qualified female candidates do make it onto boards despite many obstacles in their ways, the pathway to boardroom can be full-time company director, Private and Public Consultancy, Non-profit board works, they need to do better job of publicizing themselves and seeking recognisition for their achievements.

\section{Women must seek for Board Seats:}

Firstly, A women need to be comfortably promoting herself, talk intelligently about finances and have a resume comparable to other board members, in order to be considered for board members she should be able to make specific contributions to the companies strategic direction. To be effective members of the board no matter what the gender, directors must understand the business, have global awareness and know management processes to understand how to evaluate strategy. Board's trends today are to create independent directors who bring to management's attention any issue that seems to be relevant to the continual growth of the company; women need to be coached about how it works on the boards.

As the need for talent in the Indian marketplace begins to multiply and exposure to the dynamics of a cross cultural global strategic workplace begins to increase, company CEO's are looking at the demographic pool of women executives as a possible answer to talent crunch. This is an important time for women talents to come forward and nurture themselves as women leaders and take up challenges at the work place. Some examples have been quoted where women has proved competence and trust at the work place.

New York, April 22: PTI posted April 23, 2007.

Cola queen Indira Nooyi, President and CEO from 2006, is heading PepsiCo in US. PepsiCo tops the list of Indian-run firms. On 200 largest global companies AT\&T has six female directors on its board of 20, the largest number of women directors in any company within the Fortune listing.

Secondly, In all Major corruption exposes in the US Women played the role of whistle blower.A classical case Sherron Watkins, who exposed the Enron auditing scam. In fact, World Com's $\$ 3.8$ billion cover up was also sounded off by a women named Cynthia Cooper (Business line Internet edition 2008).

Gone are the days when Women lived their lives as dictated by society and family. The Indian Women of today has taken the reins of her personal and professional life into her own hands. The most powerful women in business from India are Kiran Mazumdar Shaw of Biocon, Radhika Balasubramanian, COO, domestic BPO operations, Intelnet, Chandini Jafri, COO, VC Circle.com, Kalpana Morpaia, ICICI, and many others yet to come on the screen.

Thirdly, According to International Labor Organization, (ILO) report $75 \%$ of world activities are executed by women, but they own mere $0.01 \%$ of the total assets. Women are almost present on all bureaucratic \& ministerial positions in India. Out of 4671 female officers in India highest bureaucratic echelon is $12 \%$. Women Cabinet Ministers 6\%. Delhi Chief Minister Sheila Dikshit said Women's inability to reach to the top positions is a global phenomenon and India is no exception. 


\section{Suggestions/Points to note:}

- It is era for women in corporate corridors in India.

- Professional Institutions and Associations should take steps to increase women registration and should frame strategies to reduce women drop outs.

- To find an increase in number of Women executives and Directors a path way should be built to follow and empower themselves to be fit to occupy board positions.

- SEBI in its guideline has not mentioned about women representation at all, in a multi religion and multi language and more orthodox families in India until and unless it is made mandatory, companies will not seek women on boards.

- The 8 Indian companies which has made its place on global fortune 500 companies has not shown fair number of women on their boards.

\section{IIIConclusion}

The goal of the study is to understand the concept of Corporate governance and the requirement of women talent pool to achieve the objectives of corporate governance, to find answer to the question whether there are enough women talents available to represent corporate boards and study those areas where there is availability of talents for the board and recalling the proving abilities exhibited by women on corporate boards around the world. The results shows that there is quite a number of women talent pool available to begin with, the women are representing the corporate boards but are very less in numbers and are not at all present on high profile companies. Even though their representation on the boards is very less on the boards there are records of proving competence and trust by women around the globe. Further study indicates that steps should be taken seriously to increase the women on fortune boards.As the boards contribute to good corporate governance practices. The boards with women members has proved competence which are important for the success story of the successful companies. However this study is not an end to itself and an answer to all the questions related to corporate governance and women directors but this is just an attempt to explore for better governance with women representations on the boards.

\section{References}

[1]. $\quad$ Press Trust of India, Fortune smiles on Indians, six company heads top US list, April 23, 2007.

[2]. Virendra Verma \& Rachna Monga, Business today, january 25,2009, The Myth of Corporate Governance

[3]. C.Jayanthi, Empowering women in india Inc. 2008-5-10, updated may 10, 2008.

[4]. Indrani Rajkhowa Banerjee, When she's is the CEO Times of India, January 18, 2009.

[5]. Paul Denning, Director of Media Relations, MITS loan management, Newsroom, 2004,tel:617-253-0576.

[6]. Judy B. Rosener, Women on Corporate Boards Make good Business Sense,Directorship, may, 2003

[7]. Poonam Barua, by invitation in the financial express, Convener, forum for womenin leadership and director, Pamasia and Regional Director-India.

[8]. Sumru Erkut, Ph.D. Critical mass on corporate boards: why three or more women enhance governance.,2006

[9]. Business wire, Fewer Women Representation in the C-suite of Fortune Global 100 Companies than in the Boardroom, september 24, 2007, eastern time.

[10]. : : A half century of incomplete or lost Agenda. Vol.4, No.2, 161-200(2000).

[11]. Bilimoria, Diana, Journal of Management Issues,March 22, 2006, The relationship between corporate directors and women corporate officers.

[12]. .Caclubindia:Forum search reasult, 12 sudder street, Kolkata u 700016 u India, Tel: 913322521031.

[13]. D.Murali, Article: Women directors can bring great value to corporate India's boardroom, by Aisha on 28 october 2007.

[14]. D.Bandopadhyay, Gender and Governance in India, economic and political weekly vol.35, No.31 (jul.29-Aug. 4, 2000)

[15]. Jennifer Lee, Inconsistency, thy name is man,CFO Asia-Dec 2006/jan 2007-Grapevine, dec 2006/jan 2007.

[16]. Ethicsworld.org, 11.9.2006, Wellesley Centre of Women's.

[17]. Anita Gurumurthy, Critical voices: Women's perspectives on the Role of the information Society in Fostering Human Development. Dec 11, World summit on the information Society, Geneva, Switzerland.

[18]. Irene Natividad, co-chair, Corporate Women Directors International, and President, Global Summit ofWomen, Women Directors in the Fortune global 200 briefing.2007.

[19]. Pawan Agarwalla, CA-Mumbai, can independent Non-esecutive directors become the directing mind and will of the corporation?,

[20]. Agarwal, Sanjiv, Corporate Governance-concept and dimensions, Snow White Publications Pvt. Ltd., Mumbai, 2003.

[21]. Balasubraminian,N., Corporate Boards and Governance, Sterling Publishers, U.K., 1998.

[22]. Flistein, Neil, The transformation of Corporate control, Harvard University Press, Cambridge, Massachusetts, 1990.

[23]. Corporate Governance compliance in Indian industries-A case study Dr. Twinkle prusty, Faculty in commerce, Banaras Hindu

Web sites: university Varanasi, UP. \& Dr. Shyam Lodha. Regal Publication New Delhi.

www.bestindissites.com

www.percentageplay.co.in

www.theequitydest.com

www.sebionline.com

www.corp.gov.net

Websites of PSUs in India. 